\title{
OXYGEN LEVELS AND HAEMODYNAMICS DURING ANAESTHESIA WITH NITROUS OXIDE, THIOPENTAL, AND CURARE*
}

\author{
Richard A. Theye, M.D., and Charles J. Restall, M.D. $\dagger$
}

Advocates of certain anaesthetic regimens often stress the apparently superior cardiopulmonary performance with specific agents and techniques. Such claims are usually difficult to support or to refute because of the scarcity of quantitative data from truly comparable clinical situations in which the anaesthetic regimen is the only major variable. This situation is due in part to the de-emphasis of clinical studies during the current expansion of anaesthesia research efforts. In addition, it is ordinarily very difficult to have available for study a reproducible clinical situation in which there is opportunity to vary only the anaesthetic agent. When such a situation became available through the interest and co-operation of a surgical colleague, we set out to determine whether certain anaesthetic regimens were inherently superior to others in terms of cardiopulmonary performance. When the need for information regarding the effects of anaesthesia on metabolism became apparent, the studies were appropriately expanded. The present study of oxygen levels and haemodynamics during anaesthesia with nitrous oxide, thiopental, and curare has been preceded by similar studies during anaesthesia with ether, halothane, and methoxyflurane. ${ }^{1-3}$

\section{Material and Methods}

Ten adults were studied during operation for varicose veins. All received pentobarbital (100 mg.) at two hours and meperidine (50 to $100 \mathrm{mg}$.$) and$ atropine sulfate $(0.4 \mathrm{mg}$.) at one hour before induction of anaesthesia with thiopental (125 to $350 \mathrm{mg}$.) and intubation with the aid of succinylcholine ( 40 to $60 \mathrm{mg}$.). Anaesthesia was maintained with a $6 \mathrm{~L} . / \mathrm{min}$. flow of $\mathrm{N}_{2} \mathrm{O}$ and $\mathrm{O}_{2}$. The flow of $\mathrm{O}_{2}$ was adjusted via the Beckman $\mathrm{O}_{2}$ Analyzer, Model \#D-2, as required to maintain the inspired $\mathrm{Po}_{2}$ at approximately $160 \mathrm{~mm}$. $\mathrm{Hg}$ (Patients 1 and 2) or $210 \mathrm{~mm}$. Hg (all other cases). Manual hyperventilation was used with a semi-closed, circle $\mathrm{CO}_{2}$ absorption system. Mean airway pressure was approximately $3 \mathrm{~mm}$. Hg. Curare (d-tubocurarine chloride) was given after intubation ( 20 to $30 \mathrm{mg}$.) and each 20 minutes thereafter ( $3 \mathrm{mg}$.). Thiopental was given in amounts of 50 to $100 \mathrm{mg}$. as required to maintain a clinically satisfactory state of anaesthesia and suitable working conditions for the surgeon. The total amount of thiopental required to achieve this state varied from 450 to $1,800 \mathrm{mg}$. and is listed for the individual patients in Table I. Intravenous fluids (5\% glucose

"Mayo Clinic and Mayo Foundation: Section of Anaesthesiology. Read at the meeting of the Canadian Anaesthetists' Society, Montreal, Quebec, June 25 to 30, 1967. This investigation was supported in part by Research Grant H-4881 from the National Institutes of Health, Public Health Service.

fRochester, Minnesota. 


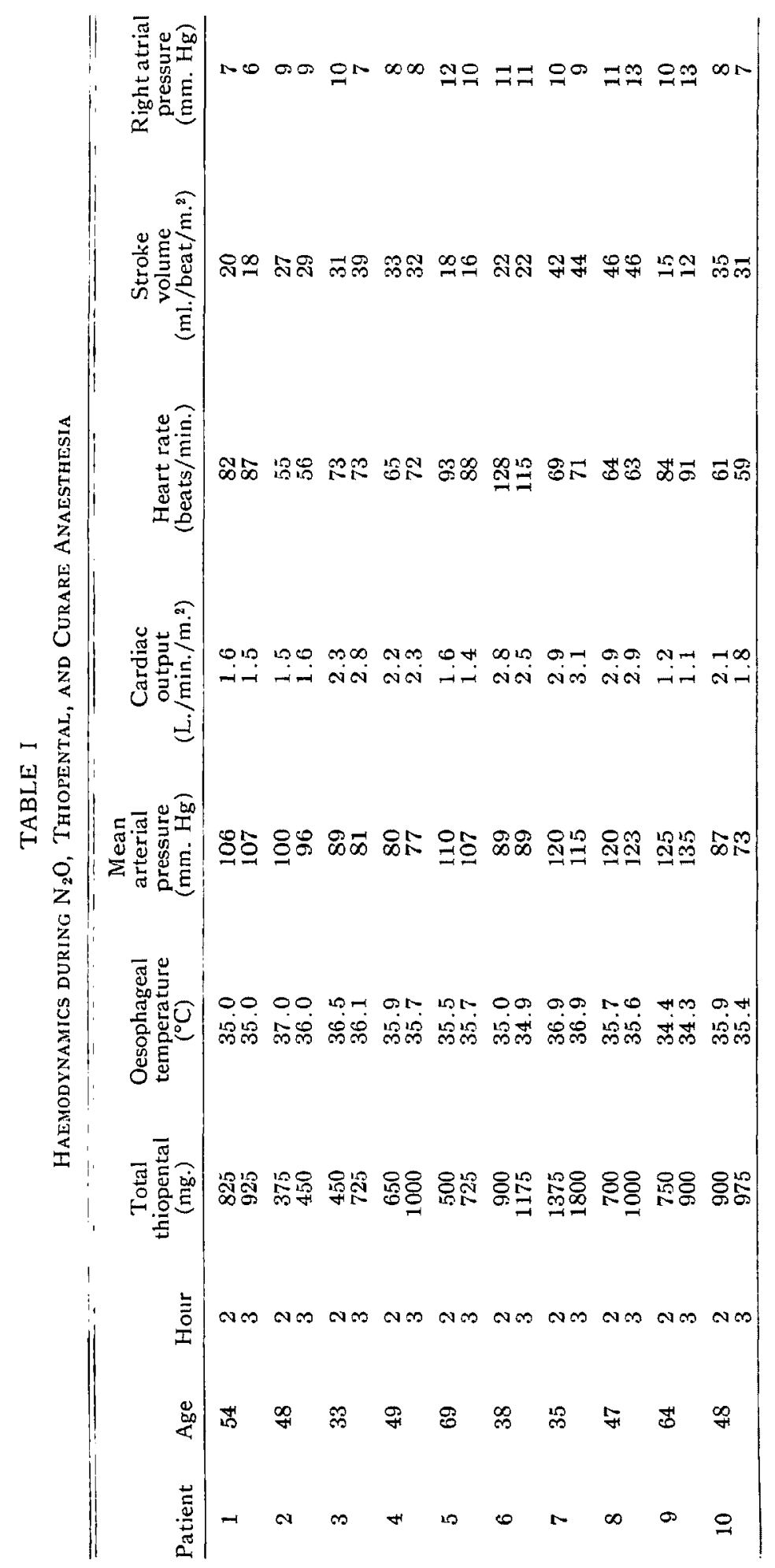


in $0.2 \%$ saline) were given at a rate of $2 \mathrm{ml} . / \mathrm{kg}$. per hour. Measurements included oesophageal temperature (thermistor); arterial blood $\mathrm{pH}, \mathrm{PcO}_{2}$, and $\mathrm{Po}_{2}$ (electrodes); $\mathrm{O}_{2}$ saturation (reflexion oximetry); haemoglobin concentration (cyanmethaemoglobin); cardiac output (indocyanine green, dye dilution); and arterial and right atrial pressures (strain gauge). In all known respects, the clinical situation studied and the methods used were similar to those of the previous studies during ether, halothane, or methoxyflurane anaesthesia. ${ }^{1-3}$

The first hour of anaesthesia was occupied with establishing arterial (Teflon needle) and right atrial (catheter advanced from antecubital vein, electrocardiographic localization) sampling and steady anaesthetic and surgical conditions. Observations were then made at consecutive 15-minute intervals during a twohour period. At the completion of these studies, measurements were repeated five minutes after $125 \mathrm{mg}$. of thiopental were administered (six patients).

\section{Results}

The haemodynamic and blood gas values observed in each of ten patients during the second and third hours of $\mathrm{N}_{2} \mathrm{O}$, thiopental, and curare anaesthesia are listed in Tables I and II. Considerable variation existed in individual total thiopental requirements ( 450 to $1,800 \mathrm{mg}$ ) and cardiac output values ( 1.1 to 3.1 L. $/ \mathrm{min} . / \mathrm{m}^{2}$ ). Low values of cardiac output for individuals tended to be associated with low total amounts of thiopental administered (Fig. 1). Values for right atrial $\mathrm{O}_{2}$ saturation were fairly normal ( 66 to $74 \%$ ) in the majority of individuals (six patients) in association with cardiac outputs of $1.8 \mathrm{~L} . / \mathrm{min} . / \mathrm{m} .^{2}$ and

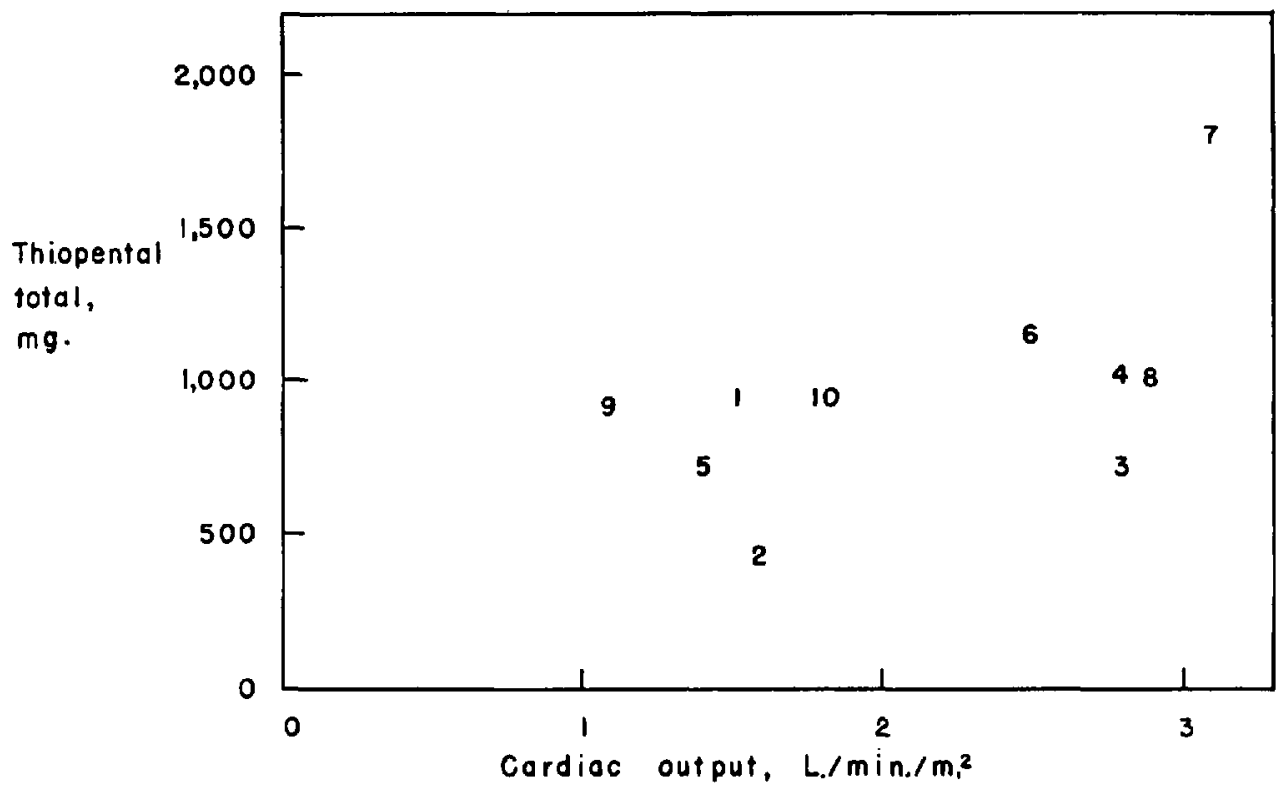

Figure 1. Average values for cardiac output and total thiopental administered for each of ten patients (individuals are indicated by the numbers used in the text). Note the lack of association of low cardiac output values with high total amounts of thiopental. 


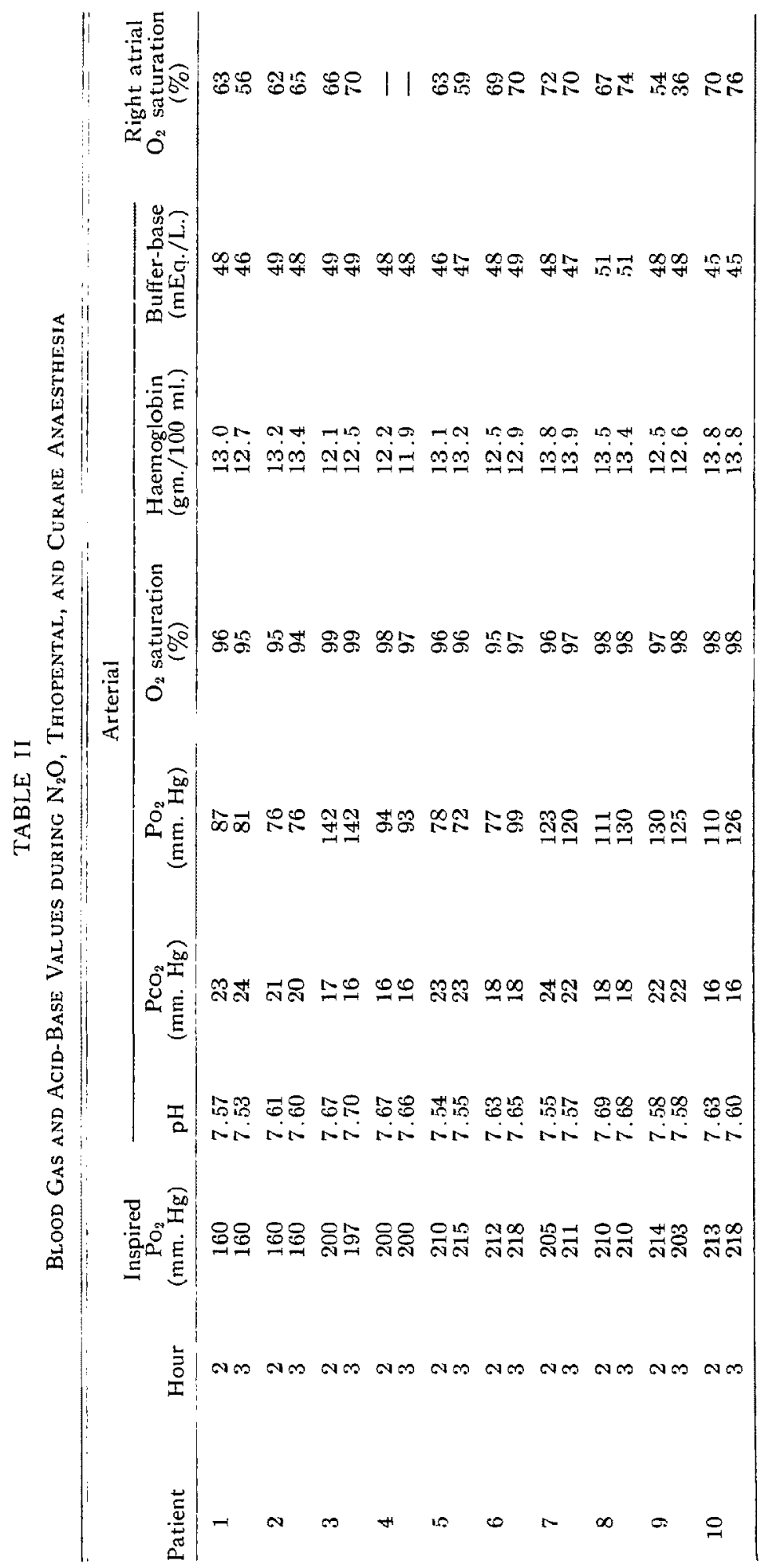


greater (Fig. 2). Abnormally low right atrial $\mathrm{O}_{2}$ saturations (65\% and lower) were noted in patients $1,2,5$, and 9 in association with abnormally low cardiac outputs ( $1.6 \mathrm{~L} . / \mathrm{min} . / \mathrm{m} .{ }^{2}$ and lower $)$. A careful study of the other observations available failed to reveal the basis of the distinctly impaired cardiac performance common to these four individuals. The reduced cardiac output was not characteristically associated with a lowered or elevated arterial pressure, heart rate, or stroke volume (Table I and Fig. 3).

The arterial blood acid-base status was similar for all (Table II) with elevated $\mathrm{pH}$, lowered $\mathrm{PCO}_{2}$, and fairly normal buffer-base values (uncompensated respiratory alkalosis). Arterial $\mathrm{Po}_{2}$ values varied considerably among patients without an apparent relation to age, inspired $\mathrm{Po}_{2}$, degree of hyperventilation, haemodynamics, or passage of time. The described differences among individuals in haemodynamic and blood-gas values remained fairly constant throughout the two hours of observation. For the group as a whole, significant change in circulatory system function with time did not occur (Table III). Cardiac output and arterial pressure were characteristically unchanged five minutes after thiopental (125 mg.), despite the presence of an increase in heart rate and reduction in stroke volume (Table IV). In comparison with other anaesthetic regimens studied,

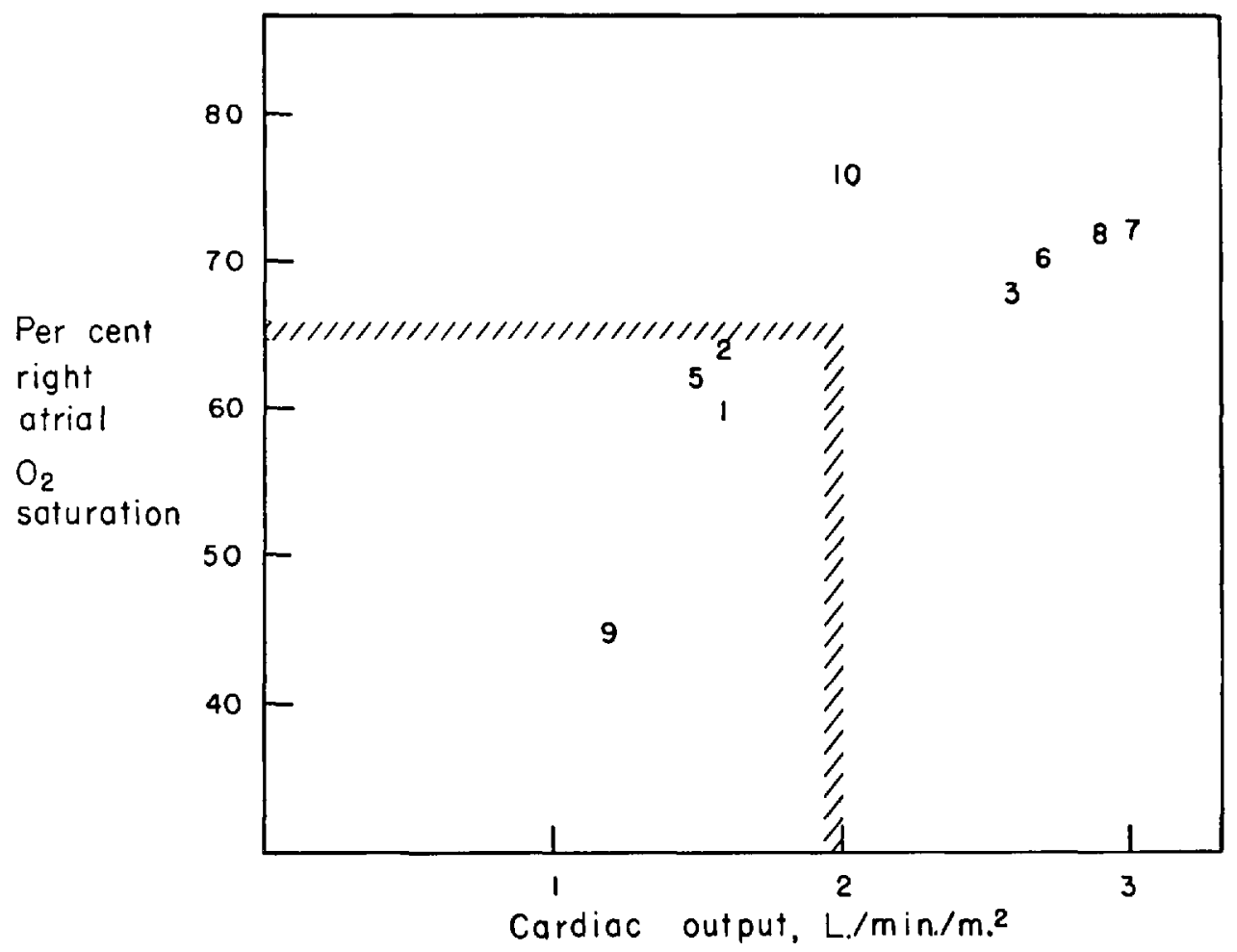

Figure 2. Average values for right atrial $O_{2}$ saturation and cardiac output in nine patients. The hatched lines indicate the lower limits of normal. Note the good agreement between abnormally low cardiac output values and right atrial $\mathrm{O}_{2}$ saturation values in patients 1,2 , 5 , and 9 . 


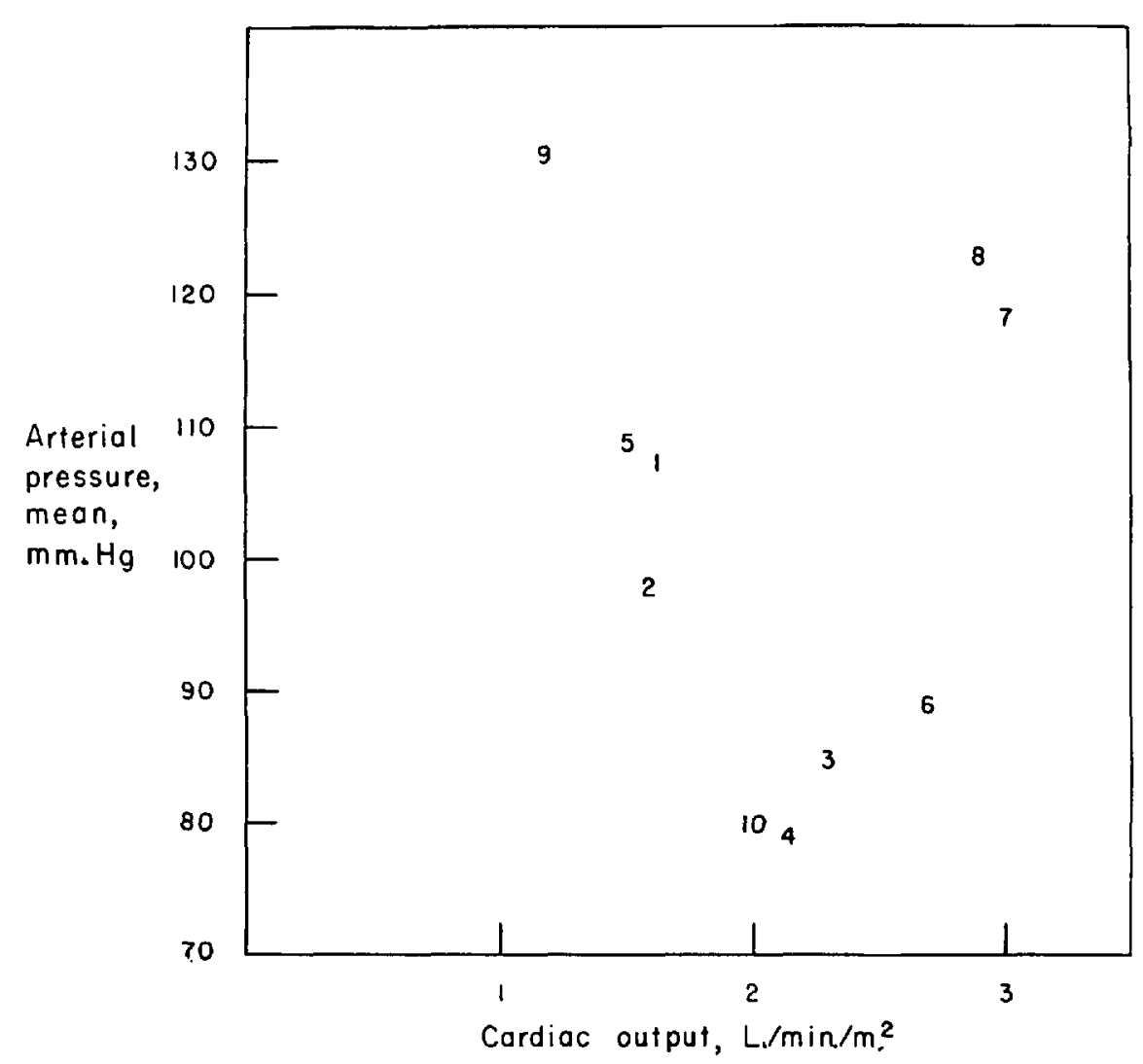

Figune 3. Average values for arterial pressure and cardiac output for each of ten patients. Note particularly that arterial blood pressure was not characteristically low in the four individuals $(1,2,5$, and 9$)$ who had demonstrated abnormally low cardiac outputs.

$\mathrm{N}_{2} \mathrm{O}$-thiopental-curare anaesthesia appears to be associated with a cardiac output midway between the greater value in ether anaesthesia and the lesser values for halothane or methoxyflurane use (Table V).

\section{Discussion}

These findings indicate that an anaesthetic regimen based on thiopental, $\mathrm{N}_{2} \mathrm{O}$, and curare is neither particularly desirable nor remarkably undesirable in the clinical situation studied. Favourable findings include comparatively high average values for cardiac output and arterial pressure, stability of individual haemodynamic and blood-gas values, and the absence of significant change in bufferbase values. Unfavourable findings are believed limited to the abnormally low cardiac output and right atrial $\mathrm{O}_{2}$ saturation values in four of the ten individuals studied.

It seems unlikely, however, that the low cardiac output values in these four patients are related solely to myocardial depressant effects of thiopental, and 

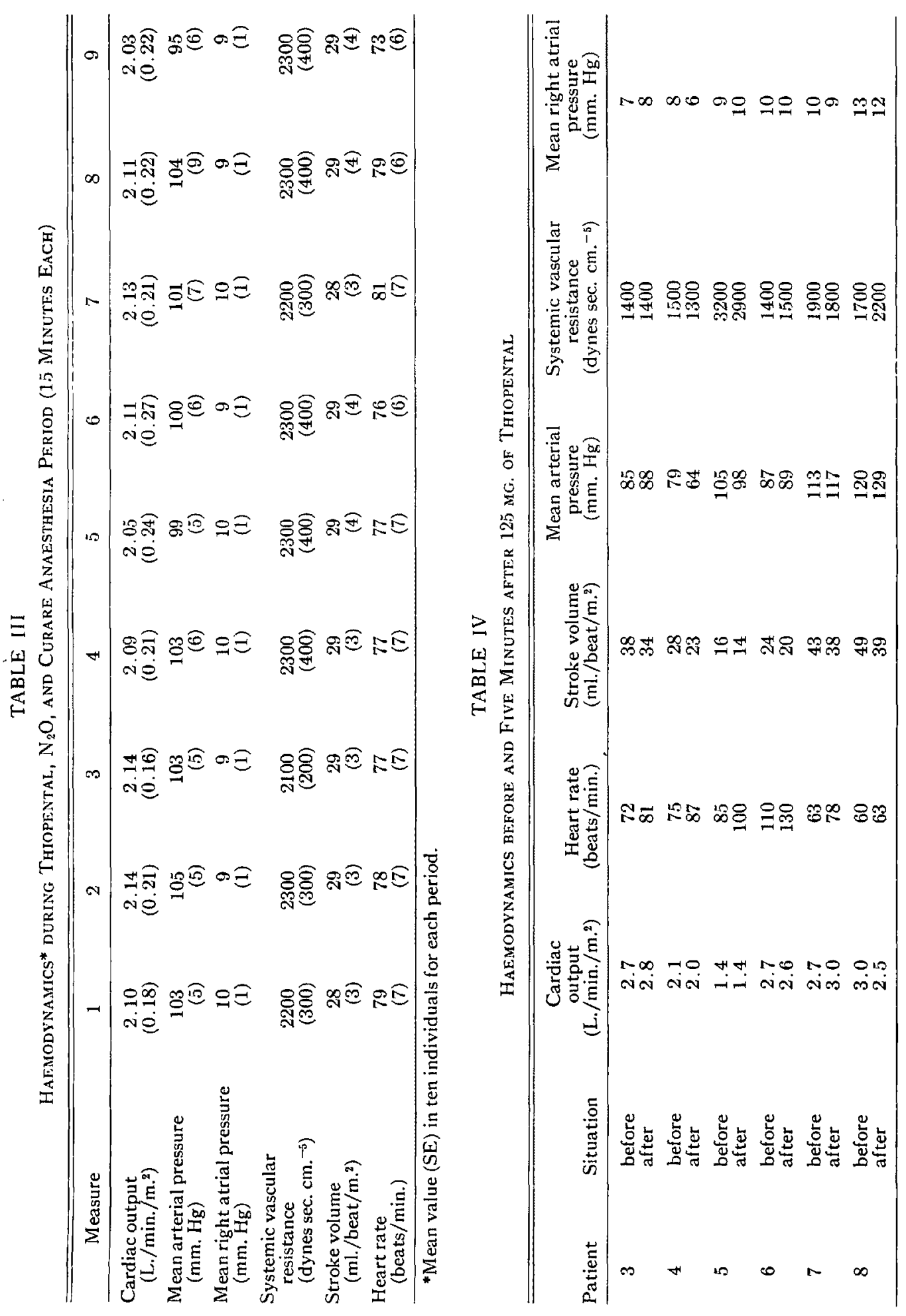
TABLE V

Comparative Haemodynamics*

\begin{tabular}{|c|c|c|c|c|}
\hline & \multicolumn{4}{|c|}{ Mean (SE) } \\
\hline & $\begin{array}{l}\text { Thiopental } \\
\text { and } \\
\text { curare }\end{array}$ & $\begin{array}{c}\text { Ethyl ether } \\
2-3 \%\end{array}$ & $\begin{array}{l}\text { Halothane } \\
0.8 \%\end{array}$ & $\begin{array}{l}\text { Methoxyflurane } \\
0.5 \%\end{array}$ \\
\hline $\begin{array}{l}\text { Cardiac ouput } \\
\left(\mathrm{L} . / \mathrm{min} . / \mathrm{m} .^{2}\right)\end{array}$ & $2.10(0.07)$ & $2.39(0.06)$ & $1.91(0.06)$ & $1.78(0.03)$ \\
\hline $\begin{array}{l}\text { Mean arterial pressure } \\
(\mathrm{mm} . \mathrm{Hg} .)\end{array}$ & $102(2)$ & $94(1)$ & $81(2)$ & $82(3)$ \\
\hline $\begin{array}{l}\text { Right atrial pressure } \\
(\mathrm{mm} . \mathrm{Hg})\end{array}$ & $9(0.2)$ & $8(0.4)$ & $11(0.4)$ & $9(0.3)$ \\
\hline $\begin{array}{l}\text { Stroke volume } \\
\quad\left(\mathrm{ml} . / \text { beat } / \mathrm{m} .{ }^{2}\right)\end{array}$ & $29(1)$ & $34(1)$ & $30(1)$ & $27(1)$ \\
\hline $\begin{array}{l}\text { Heart rate } \\
\text { (beats/min.) }\end{array}$ & $77(2)$ & $71(1)$ & $64(1)$ & $67(1)$ \\
\hline
\end{tabular}

*With each regimen, the respired gas mixture contained $60-70$ per cent $\mathrm{N}_{2} \mathrm{O}$.

for two reasons. Firstly, in this series of ten patients, the degree of depression of cardiac output was not apparently directly related to total thiopental dosage (Fig. 1). In fact, although high cardiac output values were not associated with low total amounts of thiopental, low values for cardiac output were frequently associated with low total amounts of thiopental. Secondly, administration of 125 mg. of thiopental was followed by a reduction of stroke volume, but generally cardiac output was maintained by means of an increase in heart rate (Table IV). These findings are consistent with previous demonstrations of direct myocardial depressant properties of thiopental in heart-lung studies ${ }^{4}$ but are in conflict with reports of progressive reduction in cardiac output with increased depth of thiopental anaesthesia in man..$^{5}$ Failure to demonstrate a clear, direct effect of thiopental on cardiac output in the present studies is believed to be due, in major part, to the low total amounts of thiopental administered. However, it may be that, as suggested by one reviewer, moderate surgical levels of thiopental anaesthesia do not cause myocardial depression in normal human subjects. ${ }^{6}$

The present study and others in the series ${ }^{1-3}$ rely heavily on cardiac output values in the ultimate appraisal of relative effects of a particular anaesthesia regimen on the circulatory system during anaesthesia and operation. In addition, the rate of metabolic consumption of $\mathrm{O}_{2}$ and the arterial $\mathrm{O}_{2}$ content have been measured in several situations in order to permit the evaluation of circulatory system adequacy in terms of the $\mathrm{O}_{2}$ system. In this context, values for right atrial $\mathrm{O}_{2}$ saturation have been demonstrated to be useful as an index of the relationship of cardiac output, $\mathrm{O}_{2}$ consumption, and arterial $\mathrm{O}_{2}$ content. ${ }^{7}, 8$ For example, a reduction in cardiac output without change in $\mathrm{O}_{2}$ consumption rate or arterial $\mathrm{O}_{2}$ content would necessarily be accompanied by a reduction in the value for right atrial $\mathrm{O}_{2}$ saturation. In this approach, care must be taken to remember that only the whole-body situation is considered without knowledge of events in individual organs, tissues, or cells, that variations of haemoglobin concentration can be at times an important consideration, and that values for right atrial $\mathrm{O}_{2}$ saturation may not be identical with those obtained with a true sample of mixed venous blood (pulmonary artery). 
Despite these limitations and reservations, values for right atrial $\mathrm{O}_{2}$ saturation have considerable immediate usefulness in the rapid evaluation of a clinical situation. For example, during the present study, it was known in the operating room that four patients $\left(1,2,5\right.$, and 9 ) had low values for right atrial $\mathrm{O}_{2}$ saturation and that, therefore, a disparity in cardiac output, arterial $\mathrm{O}_{2}$ content, and metabolic requirements must exist. After the dye-dilution curves were processed and cardiac output values were calculated, it was established that an abnormally low cardiac output existed in each of these patients. In this situation, blood pressure measurements and pulse rate determinations were remarkably unrevealing (Table I). From this and other experiences, we believe that the values for right atrial $\mathrm{O}_{2}$ saturation offer to the clinical anaesthetist a convenient and handy tool for rapid evaluation of adequacy of cardiopulmonary performance.

\section{SUMMARY}

Haemodynamic and blood gas studies have been carried out in ten patients during anaesthesia with $\mathrm{N}_{2} \mathrm{O}$, thiopental, and curare and during operations for varicose veins. Similar observations have been made previously during anaesthesia with ether, halothane, or methoxyflurane in the same clinical situation. With $\mathrm{N}_{2} \mathrm{O}$, thiopental, and curare, average values for cardiac output were somewhat lower than those observed during anaesthesia with ether but were somewhat higher than with halothane or methoxyflurane. Abnormally low values for cardiac output were noted in four of the ten patients, but these low values could not be ascribed to overdosage of thiopental. Values for right atrial $\mathrm{O}_{2}$ saturation were demonstrated to be useful indices of the interrelationships of cardiac output, arterial $\mathrm{O}_{2}$ content, and rate of metabolic consumption of $\mathrm{O}_{2}$.

\section{RÉSUMÉ}

On a fait des études de l'hémodynamique et des gaz du sang chez dix malades durant l'anesthésie au $\mathrm{N}_{2} \mathrm{O}$, pentothal et curare et durant des opérations pour cure de varices. Auparavant, on avait fait des observations semblables dans des circonstances identiques mais dont l'anesthésie était pratiquée à l'éther, à l'halothane ou au méthoxyflurane. Durant l'anesthésie au protoxyde-pentothal-curare, la moyenne de débit cardiaque était quelque peu inférieure à celle qu'on a observée durant l'anesthésie à l'éther, mais supérieure à celle des cas d'halothane ou de méthoxyflurane. Quatre des dix malades ont présenté un débit cardiaque considérablement abaissé, mais ces anomalies ne pouvaient être imputées à un surdosage de pentothal. On a démontré que le taux de saturation d'oxygène dans l'oreillette droite est un indice utile des rapports entre le débit cardiaque, le contenu d'oxygène artériel, et le taux de consommation métabolique d'oxygène.

\section{ACKNOWLEDGMENTS}

Our thanks to Dr. T. T. Myers, Section of Peripheral Vein Surgery, for making these studies possible, and to Henrietta Cranston and James Milde for technical assistance. 


\section{REFERENCES}

1. Theye, R. A. \& Tuohy, G. F. Hemodynamics and Blood Volume during Operation with Ether Anesthesia and Unreplaced Blood Loss. Anesthesiology. 25: 6 (1964).

2. - - Comparative Haemodynamics during Operation, Unreplaced Blood Loss, and Anaesthesia with Ether or Halothane in Nitrous Oxide and Oxygen. Brit. J. Anaesth. 36: 212 (1964).

3. Restall, C. J.; Milde, J. H.; \& Theye, R. A. Circulatory Indices of Methoxyflurane, Halothane, and Ether Anesthesia. Anesth. \& Analg. 45: 330 (1966).

4. Price, H. L. \& Helrich, M. The Effect of Cyclopropane, Diethyl Ether, Nitrous Oxide, Thiopental, and Hydrogen Ion Concentration on the Myocardial Function of the Dog Heart-Lung Preparation. J. Pharmacol. \& Exper. Therap. 115: 206 (1955).

5. Fieldman, E. J.; Ridley, R. W.; \& Wood, E. H. Hemodynamic Studies during Thiopental Sodium and Nitrous Oxide Anesthesia in Humans. Anesthesiology. 16: 473 (1955).

6. ETsTen, B. \& Li, T. H. Effects of Anesthesia upon the Heart. Am. J. Cardiol. 6: 706 (1960).

7. TheYe, R. A. \& Tuону, G. F. The Value of Venous Oxygen Levels during General Anesthesia. Anesthesiology. 26:49 (1965).

8. ThEYE, R. A. Oxygen Levels during Anesthesia and Operation. S. Clin. North America. 45: 805 (1965). 